\title{
Michal Czajkowski (Sadyk Pasha)'s Projects in The Ottoman Empire (1841-1872)
}

\author{
Volodymyr Poltorak' ${ }^{1}$
}

'Corresponding author/Sorumlu yazar: Volodymyr Poltorak (Asst. Prof.), i.i. Mechnikov Odessa National University, Faculty of History and Philosophy, Department of History of Ukraine, Odessa,Ukraine.

E-mail: poltorak@onu.edu.ua ORCID: 0000-0002-6336-9150

Submitted/Başvuru: 16.09 .2020 Revision Requested/Revizyon Talebi: 00.00 .0000

Last Revision Received/Son Revizyon: 00.00 .0000

Accepted/Kabul: 24.06 .2021

Citation/Atıf: Poltorak, Volodymyr, “Michal Czajkowski (Sadyk Pasha)'S Projects in the Ottoman Empire (1841-1872)", Güneydoğu Avrupa Araştırmaları Dergisi, 35 (2020), s. 175-188.

https://doi.org/10.26650/gaad.796116

\begin{abstract}
There should be three periods in the activity of Myhaylo Czajkowski on the Balkan Peninsula. The first is the time when Czajkowski led the Oriental mission of Hotel Lambert in Istanbul. The Concept of the South Slavic Federation, created by Adam Czartoryski, included the liberalization of the policy of the Ottoman Empire in relation to the Christian population, and the promotion of the Uniate movement among the Orthodox. The second period is the time before and immediately after the Crimean War, when Czajkowski became an Ottoman general (Sadyk) and headed the Cossack regiments. At this time, his projects became free from the influences of Czartoryski. An idea emerges about the formation of the Ukrainian-Bessarabian Principality, headed by Hetman. The third period is the 1860s, when Sadyk Pasha contributed to the proclamation of the Bulgarian Autocephalous Church, entered into an open conflict with former colleagues from Hotel Lambert and at the same time began to substantiate the concept of Pan-Slavism. Consequently, the project activity of Mykhaylo Czajkowski deserves our attention, because it played a certain positive role in the Bulgarian revival, sometimes contrary to the intentions of Sadyk Pasha. For the first time, the Bulgarians received patronage in the upper circles of the Ottoman Empire, which was marked primarily by the successful proclamation of the autocephaly of the Bulgarian church in 1870. The Ottoman Cossacks, headed by Czajkowski, positively influenced the processes of national revival in the 1860s. Cossacks laid the foundations of European cultural influence on the population of Bulgarian cities. The Cossacks softened the repressive actions of the Ottoman administration against the insurgent movement in the 1860s. Czajkowski's literary works in the "Spring of Peoples" introduced the Bulgarian people to the European reader and justified the image of Bulgarian movement for independence.
\end{abstract}

Keywords: Ottoman Empire, Bulgaria, Ukraine, Ottoman Cossacks, Nation-building, Bulgarian Autocephaly, Project Activity 
During 1841-1872, there was virtually no case in the Balkans in which Mykhajlo Czajkowski (Sadyk-pasha, 1804-1886) did not play a role, directly or indirectly. To consider Mykhajlo Czajkowski as a Ukrainian politician allows us his origins, activities, as well as political and philosophical concepts, expressed in literary works and official correspondence. We now have access to a huge amount of information about Mykhajlo Czajkowski's 30-year stay on the Balkan Peninsula, and a structured approach using the project method will allow us to take a fresh look at both the figure's creative work and its results, which for the most part turned out to be unexpected for the "project manager" himself. First of all, we will define that a "project" (in the sense of an organizational project) will be called in a broad sense "a set of efforts by one person, group of persons or organization, carried out in order to obtain specific unique results."

Mykhajlo Czajkowski was destined to become an iconic figure for the era of nationbuilding in Southeastern Europe, and his role has been noted in Polish, Bulgarian, Russian, Ukrainian, Romanian, and Turkish historiography: a Polish nobleman, an insurgent, a Turkish general, a patron of Bulgarian autocephaly and Old Believers, a Mason, a French journalist, a Cossack ataman and a Ukrainian patriot - this is a far from complete and seemingly mutually exclusive list of identifiers of this figure. Now the fantasy of the authors of the World Wide Web gives him new "titles": "James Bond of the 19th century", "The most mysterious", and finally - "Adventurer". Let's add another to this - "effective project manager", which will be discussed in more detail below.

In this study, we turn to the three most influential projects. These include the following projects: "Cossack" (definition of Ivan Lysyak-Rudnytsky), “Ukrainian-Bessarabian” and "Bulgarian Orthodox Autocephaly" (promoting the creation of an autocephalous Bulgarian church). We will also briefly refer to other projects implemented or not implemented (but started) on the Balkan Peninsula with the participation of Michal Czajkowski. The significance of these projects is all the more contradictory, the more it seems from the standpoint of the tasks of the Polish, Ukrainian and Bulgarian national movements of the mid-nineteenth century and the attitude to the future of the Ottoman Empire.

The famous Polish independence fighter Zygmunt Milkowski described his attitude to the Ottoman Empire in 1848: "We were very grateful to the Ottoman Empire for asylum, but we knew from history that our case was very similar to that of the people conquered by Turkey." Relying on their beliefs, most Polish and Hungarian rebels left the empire. The principle and purity of the ideological line in the behaviour of the revolutionary democrats very much limited the scope of their action in Turkey. More flexible in this regard was the conservative camp of Adam Czartoryski, the so-called Hotel Lambert, which tried to combine in its work in the Balkans seemingly incompatible tasks: 
1. to strength the position of the Ottoman Empire - the enemy of the Russian Empire;

2. to promote the rise of the South Slavic people and their separation from pro-Russian Slavophilism.

Great diplomatic dexterity, flexibility and political flair gave Adam Czartoryski's chief agent in the Balkans, Michal Czajkowski, the opportunity to live and operate within the Ottoman Empire for thirty years. He joined the Turkish service when the Russian government demanded his expulsion from Turkey (1850). Having reached the rank of general and commander-inchief of the Cossack corps, Czajkowski, as a Turkish pasha, repeatedly used his close ties with the ruling circles to help the Christian population in the Balkans.

Bulgarian scientists B.Pieniev' ${ }^{1}$ I.Shyshmanov ${ }^{2}$, M.Arnaudov ${ }^{3}$ in a number of their studies paid attention to Czajkowski's activities in favour of the Bulgarian national movement. Their views are largely based on excerpts from Czajkowski's memoirs published in Bulgaria by his daughter, Karolina Sukhodolska. Later, Bulgarian historiography examined Czajkowski's "Cossack Project", its influence on the proclamation of the autocephaly of the Bulgarian Church, and his personal connections with figures in the Bulgarian national movement in detail. For several decades, I. Stoychev collected materials about the participation of Bulgarians in the Ottoman Cossack regiments ${ }^{4}$, and V. Smokhovska-Petrova in two monographs and several articles addressed directly to the archive of the Prince Czartoryski ${ }^{5}$, where she found reports by Michal Czajkowski on his activities in the Balkans.

Already in our time, Bulgarian researcher E. Khadzhinikolov as well as A. Zlatanov again turned to defining the role of Michal Czajkowski and his Cossacks in the Bulgarian national movement. In two articles, they analysed the work of their predecessors and drew a logical conclusion about the overall positive impact of Czajkowski's activities between the years 1841-1872 on the Bulgarian national liberation movement.

Special mention should be made of literary studies, as Czajkowski's work had no less influence on nation-building than his military-political activities. Bulgarian scholar E. Georgiev rightly emphasized the important role of Czajkowski's novels in awakening the spirit of resistance of the Bulgarian people. However, without a careful study of Czajkowski as a politician, his literary work still cannot be properly interpreted.

\footnotetext{
B. Penev, "Istoriya na novata bolgarska literatura", T. IV Sofiya, 1936, S. 753.

I.Shishmanov, "Studii iz oblasta na bolgarskoto vozrazhdane", Sbornik Bolgarskoy Akademii na Naukite, 4, 1916. M.Arnaudov, "Neofit Khilendarski Bozveli (1785-1848)", Sofiya, 1930, S.392

I.K. Stoychev, "Kazak-alaya na Chaykovski", Sofiya, 1944

V. Smokhovska-Petrova, "Mikhal Chaykovski - Sadyk pasha i Bolgarsko vozrazhdene", Sofiya, 1973; V. Smokhovska-Petrova, "Neofit Bozveli i bolgarskiyat tserkoven vopros", Sofiya, 1964; A. Zlatanov, "Kazak alayat na Sadyk pasha", Izvestiya na intituta za istoricheski izsleduvaniya, T.32, Sofiya, 2015, S.66-78.
} 
Czajkowski's activities in the direction of creating Cossack units in the Ottoman army are reflected in a large number of published sources ${ }^{6}$ and in the literature ${ }^{7}$. In particular, the leadership of the Cossack detachments in the Ottoman army is covered (except for the abovementioned Bulgarian) in the works of the Polish ${ }^{8}$, Russian ${ }^{9}$, Turkish ${ }^{10}$ and Ukrainian ${ }^{11}$ historians.

\section{Cossack Project}

Cossack units in the Ottoman army in the middle of the nineteenth century dated back to earlier centuries. Thus, in the 17th century, right-bank Cossack regiments took part in the wars against the Commonwealth and the Moscow Empire in the 18th century - in the Prut War (1711-1714), in the 19th century - during the Russo-Turkish wars of 1806-1812 and 18281829. On the eve of the last ones of these wars, the Cossacks received the status of a regular unit when the Silistra Regiment was formed. Thus, Michal Czajkowski put forward the idea of "restoration" of the Ottoman Cossacks, not the creation of it. That happened on October 20, 1853, when Sultan Abdul-Majid issued a decree to Mehmed Sadyk-bey (Michal Czajkowski was given this name after his conversion to Islam) to form a "regiment of Ottoman Cossacks." Polish historiography notes the Polish affiliation of most of these divisions ${ }^{12}$. However, given the discovery of new sources (or simply a consistent reading of the old ones), the multinationality of the Cossack regiments created in the Balkans became apparent as well as their exclusive role in the future formation of the Bulgarian armed forces.

6 “Zapiski Mikhaila Chaykovskogo (Sadyk Pashi)", Kiyevskaya starina, 1891, 1892; M.S. Chaykowskiy, "Zapiski”, Russkaya starina,1895-1898, 1900, 1904; M.Czajkowski, "Pamietniki Sadyka Paszy Michal a Czajkowskiego" / tlumaczyl na polskie A.P., Lwow, 1898; Ye. Rudnits'kiy, “Do istoriyi pol's'kogo kozakofil'stva”, Za sto lit, Kn. 1, 1925, S. 62-66; T. Slabchenko, "Koly povernuv na Ukrayinu Sadyk-Pasha?" Zapiski Istoriko-Filologichnogo Viddilu Vseukrayins'koyi Akademiyi Nauk, Kn. XXV, K., 1929; M. Czajkowski, “Moje wspomnienia o wojnie 1854 roku", Warszawa, 1962.

7 J. Chudzikowska, “Dziwne życie Sadyka Paszy o Michal e Czajkowskim”, 1971; V.Smokhovska-Petrova, “Mikhal Chaykovski - Sadyk pasha i Bolgarsko vozrazhdene”, Sofiya, 1973; D.Sen', A.Prigarin “Panslavizm Mikhala Chaykovskogo i istoriya kazachestva v Osmanskoy imperii", Polyaki v istorii Rossii: istoriya i sovremennost', Krasnodar, 2007, S.147-160; O.Prigarin, “"Kozatstvo v Turechchini» M. Chaykivs'kogo yak dzherelo vivchennya kozats'kikh formuvan' v Ottomans'kiy Porti seredyny XIX st.", Naukovi pratsi istorichnogo fakul'tetu Zaporiz'kogo derzhavnogo universitetu, 2001, Vyp. XIII, S.26.

8 Fr. Rawita-Gawronski, “Michal Czaykowski (Sadyk-pasza). Jego zycie, dzialalnosc wojskowa i literacka. Zarys biograficzny”, Petersburg, 1901; P. Wierzbicki, “Dziennik generala Feliksa Breanskiego, dowodcy brygady w Dywizji Kozakow Sultanskich", Akta THL v Paryzu, 2000, T. 5; Alisiya Kulets'ka, "Pomizh Pol'shcheyu, Turechchinoyu i Rosiyeyu: Mikhal Chaykovs'kiy (Mekhmet Sadik pasha) i problemi “kozachchini” v XIX st.", Prichornomors'kiy region u konteksti svitovoí politiki: istoriya ta s'ogodennya, Odesa, 2008, S. 117-125.

9 Yu. Borisonok, “Ataman Sadyk-pasha”, Rodina, 1998, №5-6.

10 Musa Gümüs, "Mehmed Sadik Pasa (Michal Czajkowski) ve Osmanli devlet'nde kazak suvari alayi”, Turkish studies, V. 5/3, 2010, P.1362-1375; Candan Badem, “The Ottoman Crimean War (1853-1856)", Leidem-Boston, 2010; Metin Ünver. “Wanda ya da Mehmed Sadık (Cayka) Paşa'nın Türkiye Anekdotlari”, Tarih Dergisi, 65, 2017, s. 99-118.

11 I.Lysyak-Rudnits'kiy, “Kozats'kiy proyekt Mikhala Chaykovs'kogo pid chas Krims'koyi viyny: analiz idey”, Lisyak-Rudnits'kiy I. Istorichni ese, K., 1994, T. 1, S. 251-263; V. Poltorak, “Dokumenty pro M. Chaykovs'kogo v Derzhavnomu arkhivi Odes'koyi oblasti», Chornomors'ka mynuvshina, Vyp. 5, Odesa, 2010.

12 S.Łątka Jerzy, “Słownik Polaków w Imperium Osmańskim i Republice Turcji”, Kraków, 2005, S. 19-20. 
Recruitment to the Ottoman army took place through the gathering of a Muslim male population between the ages of 20 and 25 by lot (kur'a). Recruits could send a replacement instead. Military service in the Ottoman army lasted for six years in active form and then for seven years in reserve (redif). Non-Muslims did not serve in the army, instead they paid a per capita tax (cizye, after 1855 called iane-i askeriye). However, Turkish historians note that patriotic feelings began to grow among the Ottoman non-Muslim population at the beginning of the war of 1853-56. 3,000 Bulgarians from noble families expressed a desire to join Ottoman army volunteers, according to the German newspaper Berliner Zeitung of September 1, 1853. They were not accepted. Also, some patriotic Ottoman Armenians and Greeks from Saruhan and Izmir turned to the Porte, wanting to serve in the army; the appeal was politely rejected. Thus, the Ottoman Empire, with a total population of about 35 million, roughly equal to half the population of the Russian Empire at the time, had far fewer resources to include in its army, as it depended on its Muslim population while Russia could replenish the army with a much larger population (about four times).

Thus, the Cossack regiment (alay) led by Czajkowski was a unique unit for the Ottoman army, which included representatives of the Christian population of the empire. According to the Turkish historian C. Bagdem, the Porte cautiously did not call these regiments Slavic or Polish, preferring to use the name Cossack instead. The Ottoman leadership was also careful not to recruit Polish and Hungarian officers near the Austrian border,- because the Porte had previously given guarantees to Austria ${ }^{13}$.

The Sadik-bey's Cossack regiment joined the Rumelia army led by Omer Pasha and was used to counter the Russian Cossacks in General Paskevich's army, which laid siege to the fortress of Silistra ${ }^{14}$. There the Cossacks distinguished themselves with several successful operations, and later they were the first units to have entered the Russian-abandoned Bucharest. Sadyk-Bey was currently promoting Cossack ideas among the Orthodox population of the Balkans actively, while coming into conflict with Polish officers and the British command. He spoke negatively about one of the officers, who, "like most English officers who bought their posts but did not receive them for service and accomplishment, treated their sub-officers like Slaves"15.

In April 1855, Czajkowski was sent to investigate the possibility of admitting Christians into the military service. Czajkowski's report provided the Grand Vizier with controversial points as to whether Christian volunteers could be drafted into the army. He wrote that cavalry units could be recruited from Tarnovo, Tisza, Jeni Pazar, and Sarai-Bosna, and infantry from Mostar, Iskodra, loannina, and Thessaloniki. Czajkowski wrote in his memoirs that the

13 Candan Badem, “The Ottoman Crimean War (1853-1856)", Leidem-Boston, 2010, P. 50-51.

14 Ibid, P.185.

15 lbid, P.243. 
Sultan wanted the project to be discussed with representatives of major European powers. ${ }^{16}$. However, according to his recollections, they did not like the idea. Lord Stratford de Radcliffe even told him that such a project would not be approved because then in a few years the Christian subjects of the Ottoman Empire would have a whole army that was well trained and capable of fighting. "This is not our task," Lord Stratford seemed to say to Czajkowski. Austria was in the same state of fear: the emergence of a military spirit among the Ottoman Slavs. Thus, the Porte met with opposition from all sides and eventually Western powers did not allow it to carry out this reform ${ }^{17}$.

A particularly valuable source that characterizes the development of the structure of the unit during the Crimean War (1853-1856) is the "List of officers of the Ottoman Cossacks"18. It should be noted that the information gathered in the document about the officers of the Cossack corps can be considered reliable (published immediately in Paris for propaganda purposes, but under the meticulous eye of the Polish democratic opposition - so the information about people and their achievements is unlikely to be systematically falsified). "List of officers of the Ottoman Cossacks" contains the names of 180 people, painted at the main headquarters, two regimental headquarters and regiments of Cossacks and Ottoman dragoons. Information on the ranks, positions and awards of officers is also provided.

The list of dead, as it contains information about the time, circumstances and place of death of the officer, gives us the opportunity to trace the main features of the combat path of the corps. In 1853, not a single officer was killed; in 1854, the places of death were Gropa-Chorba, Girlitz, Maksymenie; in 1855, - Zhurilovtsy, Topali, Aydimirze, Tulcea; in 1856, - Salmania, Varna, in 1857, - Istanbul, Terkas. In general, the statistics of the dead look interesting - 3 centurions (Nekrasovites), 1 Ukrainian (from the Bug Uhlans), 2 Volynians, 2 Pavlograd hussars, and 1 Pole (gunner). As we can see from this list, the national composition of the corps was diverse, and besides, there was no systematization in officers' affiliation to one or another nationality. Therefore, the data on the affiliation of officers to one or another nationality (except for the already mentioned dead officers, against whom this nationality was indicated) were determined by us according to the peculiarities of spelling surnames. This method does not seem to us accurate, much less exclusively correct, but in general, it depicts the situation in the case. Thus, the national composition of the officer corps was as follows (estimated by name, surname or other characteristics): 123 Poles, 59 others (1 Ukrainian, 13 Serbs and Bulgarians (Orthodox), 4 Italians, 2 French, 11 Germans or Jews, 5 Hungarians, 1 Wallachian or Moldavian (Romanian), as well as 12 Muslims ( 4 in the headquarters, 5 in the headquarters of the 1st Regiment, 1 in the 1st Regiment, 2 in the headquarters of the 2 nd Regiment) and 10 Nekrasovites). That is, two thirds of the officers in 1857 were Poles, and

16 M.S. Chaykowskiy, "Zapiski", Russkaya starina, 1904, T.35, dekabr, S.573.

17 Candan Badem, “The Ottoman Crimean War (1853-1856)", Leidem-Boston, 2010, P. 341-342.

18 Michał Czaykowski, “Kozaczyzna w Turcyi”, Paryż, 1857. 
a third was of other nationalities (Bulgarians, Turks, Albanians, French, Hungarians, etc.).

Thus, for 17 years, Michal Czajkowski headed a unique military unite for the Ottoman army corps of Ottoman Cossacks - the only non-Muslim unit in the territory under the jurisdiction of the Ottoman Porte. During these almost two decades, the Cossacks under the leadership of Sadyk Pasha took part in the Crimean War, performing security and even police functions. The period of 1860-1870 in the history of the Ottoman Cossacks needs a separate study. It was then that the Cossacks were replenished with Bulgarian reservists and took part in some operations against the Bulgarian insurgent detachments.

The problems associated with the role that the Cossacks played in the life of the Bulgarian people were most elaborated in the works of Ivan Stoychev. He found many documents that confirmed the cases of Cossack protection on the rights of the Bulgarian population. The people who called the Cossacks "our army" would look at the "Christian cross on the regimental flags" and listen to the commands in the Slavic language. Where the Cossacks lived, the Muslims did not dare to oppress the Christians because Sadyk severely punished every crime, and for more serious offenses he reported directly to Istanbul. After the liquidation of the first and second Bulgarian legions in Serbia, these regiments were the only military school for the Bulgarians, and Stoychev considered them the third Bulgarian legion. As a man with a military education, Stoychev praised the military training of the former Cossacks of Sadyk Pasha.

Stoychev also emphasizes the cultural role that the Cossacks played in the life of Bulgaria. The "European" way of life of Cossack officers and their families impressed the inhabitants of Bulgarian cities and aroused the desire to imitate them. Citizens began to visit, arrange dinners, and talk "in the cabin." At the Sliven casino in Poland, the intelligentsia of the city was going to read newspapers and argue. The Cossacks had their own regimental orchestra (the conductor's assistant was a Bulgarian), and the church choir sang on Sundays in local churches "to the great joy of the Bulgarians." The Cossacks studied with the choir and orchestra in various school and church celebrations, played Bulgarian folk songs, which were forbidden to be performed by local orchestras and even revolutionary songs. Stoychev also managed to establish that Sliven and its environs owed Sadik Pasha a calmer course of repressions of Midhat Pasha between 1867 and 1868.

The question about the attitude of the Bulgarian Cossacks to the Chetnik movement is interesting. Ordinary Bulgarian Cossacks, guided by a "strong people's instinct", fled from the Cossack ranks and joined the rebels. Yet, the trumpeters in Botev's detachment were just such defectors. Moreover, due to the large number of Bulgarians among the Cossacks, the Chetniks were often warned of the offensive, and they retreated in time. Polish officers looked at such actions through their fingers. In this disguised assistance to the Chetniks by the Cossacks can be seen as a source for the emergence of legends about the meeting between Czajkowski and Christ Botev, Botev's service in the ranks of the Cossacks, the non-existent agreement between Czajkowski and Levsky. 
It should be added that the very principle on which the Ottoman Cossacks were based -the principle of equality between Christians and Muslims- had a positive effect on the Christian masses, who for centuries claimed their slavish fate. The Bulgarians carried out active propaganda among the population in favour of "their regiments."

At the end of his study, Ivan Stoychev wrote that the Cossacks, with all their shortcomings, were more useful than harmful to the Bulgarian national movement. As soon as the situation in the Ottoman Empire ceased to be favourable for such a unit in the early 1870s, Czajkowski resigned and returned to Ukraine ${ }^{19}$. The subsequent fate of the Ottoman Cossacks was little different from other cavalry units of the Ottoman army.

\section{Ukrainian-Bessarabian Project}

One of the key issues in the study of Michal Czajkowski's political concept for the further development of South-Eastern Europe is the problem of the authenticity of two documents signed by members of the Committee of Ukraine and Bessarabia, dated September 16, 1853. Eugene Rudnytsky first published these two memoranda. According to him, the papers were handwritten by Adam Czajkowski (Mikhail's son) in Russian from French translations made by Ludwik Snyadetska for Adam Czartoryski. Yevhen Rudnytskyi suggests that their originals were in Ukrainian, but his arguments are weak. After all, the Ukrainianisms as called by the historian are introduced into the text by the translator Adam Czajkowski (and in fact may be Polonisms). And how would Ukrainianisms be preserved with a double translation into French and then from French into Russian?

The Committee of Ukraine and Bessarabia attracted the attention of Ukrainian historians in exile. According to Mykola Rybak, these papers allowed Sultan Abdul-Majid to issue a "firman" appointing Czajkowski "the initial leader of all the Cossacks subject to Turkey." It is also important that, according to Rybak, Czajkowski's approval of the Committee's documents led to "great indignation in the Polish exile camp" 20.

Ivan Lysyak-Rudnytsky, turning to the analysis of Mykhailo Czajkowski's "Cossack Project", could not avoid the question on the authenticity of the Committee's documents. He was "fascinated", but also "surprised" by the fact of the existence of a secret separatist organization in the middle of the 19th century, when the Ukrainian movement in general in the 19th century was not separatist, but autonomous, i.e. aimed at cultural self-expression or federalization of the Russian Empire. Considering it quite possible that "the memorandum was fabricated by Czajkowski himself because the ideas expressed in it were suspiciously similar to his own," Ivan Lysyak-Rudnytsky regrets the impossibility of finding the original papers. The historian assessed the origin of the documents published by Yevhen Rudnytsky as follows: "since they came from Czajkowski's son, it is possible that they were forged by

19 I.K. Stoychev, “Kazak-alaya na Chaykovski”, Sofiya, 1944

20 M. Rybak, "Mikhaylo Chaykovs'kiy - Megmet Sadik Pasha», Al'manakh ukrains'kogo natsional'nogo soyuzu, New York, 1971, S. 90-91. 
Czajkowski himself." Separately, Lysyak-Rudnytsky criticizes the list of signatures under the documents. And although with the participation of Omelyan Prytsak, it was allegedly possible to identify one person, Major General Dabizh, an Ukrainophile-Mazepist, but in general the mentioned signatories could not be identified. Ivan Lysyak-Rudnytskyi summed up his research writing that "This forgotten episode is interesting and important, and has more value than previously thought" 21 .

Information about the Committee of Ukraine and Bessarabia appeared in the pages of Michal Czajkowski's memoirs. These memoirs have come down to us in several versions. The first can be considered the original sketches in Polish, written between 1870 and 1886 in Istanbul, Kiev and Chernihiv. They came into the hands of Sadik Pasha's son, General of the Russian Army Adam Czajkowski, who in turn passed the memoirs to the editors of "Kyiv Antiquities" for publication. In 1891, they were partially published, brought to the 1840 s, but later publication ceased ${ }^{22}$. The second edition, which was based on the memoirs of Sadyk Pasha, is an article by his daughter Karolina Sukhodolska ${ }^{23}$ about the participation of Bulgarians in the Cossack units of her father. It is known that this version of the memoirs was written in French and was probably a sketch of the memoirs written before Czajkowski's departure for Ukraine in 1872. Traces of this text are lost - the archive of K. Sukhodolska has not been found to this day. She died in 1902 in Trieste (then the Austrian Empire). The first version of the memoirs reappears in 1895 in Moscow, where the editors of "Russian Antiquity" through Adam Czajkowski undertook to publish them ${ }^{24}$. The most complete version of Sadyk Pasha's memoirs to date has been published in this magazine for almost a decade. It was in this publication that the Committee of Ukraine and Bessarabia was first mentioned - that it was the Committee's two appeals that compromised Czajkowski's idea in the eyes of the British allies (Lord Palmerston). ${ }^{25}$.

On behalf of Michal Czajkowski, we can learn more about the Committee in the memoirs on the events of the Crimean War published in $1962^{26}$. According to him, Czajkowski admits that the Committee's papers have become one of the arguments in the internal Polish struggle over the Ukrainian issue. Czajkowski's opponent, Wladyslaw Zamojski, displayed copies of memoranda that were sent to Adam Czartoryski among Polish emigrants to prove Sadyk Pasha's separatist activities, whom he had "announced as the new Bohdan Khmelnytsky."

21 I. Lysyak-Rudnits'kiy, “Kozats'kiy proyekt Mikhala Chaykovs'kogo pid chas Krims'koyi viyny: analiz idey”, Lisyak-Rudnits'kiy I. Istorichni ese, K., 1994, T. 1, S.251-263.

22 "Zapiski Mikhaila Chaykovskogo (Sadyk Pashi)", Kiyevskaya starina, 1891, 1892

23 K. Sukhodolska, "Bolgarite v neizdanite memuari na Chayka Chaykovski (Sadyk-pasha)", Sbornik za narodni umotvoreniya, nauka i knizhnina, Kniga X. Sofiya, 1894, S.429-468.

24 M.S. Chaykowskiy, "Zapiski” Russkaya starina,1895-1898, 1900, 1904

25 M.S. Chaykowskiy, "Zapiski" Russkaya starina, T.96, 1898. №12, S. 682.

26 M.Czajkowski “Moje wspomnienia o wojnie 1854 roku”, Warszawa, 1962, S. 24-25. 
Memoirs published in 1962 explain the origin of the documents as if they had been handed over to the influential Turkish politician Reshid Pasha (a supporter of the Tanzimat, 6 times the Grand Vizier of the Empire) by two Cossack merchants from Chisinau. The originals were printed in Russian. Then, Michal Czajkowski in his memoirs as a whole conveyed the content of the above documents.

Analyzing all currently known versions of the texts of the Committee's documents, as well as accompanying documents on the events of October-November 1853, when these papers first came to the attention of Turkish officials and Michal Czajkowski himself, two assumptions can be made. Most likely, the text is a forgery. After all, he was never mentioned in well-known sources independent of Czajkowski. The style, confusing terminology, and naive pathos of the appeal, which is uncharacteristic of the Dnieper Ukrainian texts of the time, also speak of falsification. The question is who created these documents and why.

The first version is that since Rashid Pasha handed over the papers to Czajkowski, who had already distributed their translations to the Polish community, and the French translation to the Sultan, the papers may reflect the Turkish politicians' vision of the future of Southeast Europe. The protectorate of Ukraine and Bessarabia as Wallachia and Moldova was to become a buffer between the Ottoman and Russian empires. The probability of this fact is indicated by some terms - Russia is called "North" (although this is also typical of the French geographical classification, which was close to Michal Czajkowski), and so on. The restored Ukrainian hetmanate was thus seen as a continuation of the deep traditions of Cossack-Turkish relations.

The second version - already stated by Ivan Lysyak-Rudnytsky - is the most plausible. Michal Czajkowski himself could have been the author of the papers, as both documents very accurately convey key moments of his political conception known from other sources. Putting in the mouths of the representatives of Ukraine (meaning the Right Bank, because the context shows that Little Russia is considered separately - i.e. the Left Bank) and Bessarabia, a request to take these territories under the sultan, elect a hetman, provide military assistance, etc. Michal Czajkowski justified his further planned military operations and political actions. The fact of Czajkowski's authorship is also confirmed by a detailed description of the flag of the planned Cossack army, which Ottoman Empire was supposed to provide. It is like two drops of water like the flag that was solemnly raised over the Cossack hundreds in November and proclaimed "the ancient standard of Hetman Petro Doroshenko" (an unclear question as to how delegates could depict this flag in September, found in Konstatninople patriarchate in November).

The two mentioned memoranda are the result of the work of Michal Czajkowski, and may have been created with the help or with the participation of Reshid Pasha. They substantiated the participation of Ottoman Cossacks in military operations for the liberation of Ukraine and the formation of a separate autonomous Cossack Hetmanate of Ukraine and Bessarabia as part of the Ottoman Empire. In this light, we have before us a unique monument of political 
thought of the mid-nineteenth century, which raised questions about the subjectivity of Ukraine (Right Bank) and its autonomous status. The documents do not contradict (and reflect in general) the visions of Turkish politicians in the mid-nineteenth century of the future Black Sea region, and at the same time split the Polish emigration camp.

\section{Bulgarian Orthodox Autocephaly Project}

The task of Hotel Lambert and Czajkowski himself in the 1840s regarding the southern Slavs seemed to be ambiguous - to cut off from Russian influences, which means among other things, to strengthen ties with the Ottoman Empire.

Czajkowski, as Czartoryski's chief agent, developed a wide range of activities that, in a number of outcomes, proved useful to the southern Slavs. First of all, he acted as a mediator between Porto and the local Christian population and repeatedly defended its interests. From materials published by Wanda Smohovska-Petrova back in 1973, it is clear that “Czajkowski's agents controlled the actions of the Turkish authorities on the ground; the agents' reports and reports were sent directly to the Porte, which often reviewed the decisions of its representatives."

Czajkowski, in the period between 1844 and 1846, revealed Czartoryski's concept to the Bulgarian clergy - it consisted of the liberation of the Bulgarian church from Phanariot oppression, the national self-determination of the Bulgarian people. Czajkowski worked hard to implement this project. The idea of the union of the Bulgarian Church with Rome proved at that stage to be a profitable tactical step in the fight against oppression. After the conversion to Islam in 1850, Czajkowski did not stop supporting the Bulgarian church struggle as did Czartoryski's new agents. But the situation became controversial, as Czajkowski (Sadyk) supported Bulgaria's desire to create an independent Bulgarian church based on personal considerations, while Hotel Lambert's agents worked for purely ideological reasons in favour of union with the Catholic Church. Vladislav Yordan, the new chief agent of Hotel Lambert in Istanbul, testifies to the change in the attitude of Czajkowski, who became a Turkish pasha. In his report in January 1862, he expressed outrage that Sadyk Pasha had intervened in the Uniate movement and supported the aspirations of the Bulgarians for an independent church. Czajkowski, using close ties with Kibryzli Pasha (then Grand Vizier), submitted a petition of Plovdiv citizens to the Porte government requesting the establishment of an independent Bulgarian church. He continued to maintain ties with the autocephalous through Ranov and Stoyan Chomakov. When the sultan issued a decree on an independent Bulgarian church in 1870, Czajkowski's Cossack detachments greeted the reading of the sultan's firm with a music parade, as Sadik rightly believed that his work in proclaiming the Bulgarian church was a success ${ }^{27}$.

How to explain this unexpected change in Sadik's attitude to the Bulgarian church issue? In the next period of his life, when Czajkowski asked the Russian tsar for pardon and returned

27 V.Smokhovska-Petrova, “Mikhal Chaykovski - Sadyk pasha i Bolgarsko vozrazhdene”, Sofiya, 1973, S. 188-189. 
to Ukraine, he explained his patronizing attitude to the Bulgarian struggle for an independent church by ideological arguments and attacked the Poles no less sharply than G. Rakovsky for their attempts to convert the Bulgarians to Catholicism. He claims in his memoirs that he always worked for the independent Bulgarian Church and against the union with Rome because he was convinced that Orthodoxy was the only correct religion of the Slavs. In a pathetic phrase, he testified that he invariably opposed the spread of Catholicism among the southern Slavs, who did not need another religion because they had "their own Orthodox Slavic Church, founded by Cyril and Methodius." But in fact, as is known from the documents, Czajkowski, even in 1861, did not deny the movement of the Bulgarians towards a union with Catholicism. Later, seeing that new agents of the Hotel Lambert, led by Vladislav Jordan, had emerged at the head of the Uniate movement launched after the Crimean War by Dragan Tsankov and the Macedonian Bulgarians, Sadyk Pasha changed his attitude toward the Uniates. In 1866, he became a consistent supporter of the formation of Orthodox Bulgarian autocephaly. In 1866, Czajkowski wrote from Sliven to his comrade Bystronovsky: “As for the Bulgarians, I repeat that they should be given a national church."

Taking into account his personal views, proclaimed in his literary works, Sadyk Pasha spoke in favor of the Bulgarian church struggle. It was in the cities where the Cossacks were stationed (Sliven, Kotel, Yambol, Gabrovo, Shumen) that the church struggle took bolder and more decisive forms. In the eyes of the local Turks, the Bulgarian church and school movements gained more authority and weight, as Sadyk Pasha as a high-ranking military figure publicly declared his support for them ${ }^{28}$. Czajkowski's public position undoubtedly had an encouraging effect on Bulgarian teachers and students.

\section{Conclusion}

There were three periods in Michal Czajkowski's project activity in the Ottoman Empire. The first was the time when Czajkowski headed the Eastern Mission of the Hotel Lambert in Istanbul. The concept of the South Slavic federation, created by Adam Czartoryski, provided for the liberalization of the Ottoman Empire's policy towards the Christian population and the promotion of the Uniate movement among the Orthodox. The second period was the time before and immediately after the Crimean War, when Czajkowski became the Ottoman military and headed the Cossack corps. At this time, his projects became free from the influence of Czartoryski. The idea of forming a Ukrainian-Bessarabian principality was headed by a hetman who appeared. The third period was the 1860s, when Sadyk Pasha promoted the proclamation of the Bulgarian Autocephalous Church, entered into open conflict with former colleagues at the Hotel Lambert, and at the same time began to justify the concept of Panslavism.

28 Ye.Khadzhinikolova, “Mikhail Chayka-Chaykovski (Mekhmed Sadyk pasha) i bolgarite v Tulchanski sandzhak (50-70-te godini na XIX v.)", Chornomors'ka mynuvshyna, 2010, №3 
Thus, Michal Czajkowski's project work deserves our attention because it played an important role on the Balkan Peninsula, sometimes contrary to Sadik Pasha's intentions. For the first time, the Bulgarians received a patron in the upper circles of the Ottoman Empire, which was marked primarily by the successful proclamation of the autocephaly of the Bulgarian Church in 1870. The Ottoman Cossacks, led by Czajkowski, had a positive influence on the processes of national revival in the 1860s. The Cossacks laid the foundations of European cultural influence on the population of Balkan cities. The Cossacks softened the Ottoman administration's actions against the insurgent movement in the 1860s.

Peer-review: Externally peer-reviewed.

Conflict of Interest: The author has no conflict of interest to declare.

Grant Support: The author declared that this study has received no financial support.

Hakem Değerlendirmesi: Dış bağımsız.

Çıkar Çatışması: Yazar çıkar çatışması bildirmemiştir.

Finansal Destek: Yazar bu çalışma için finansal destek almadığını beyan etmiştir.

\section{Bibliography}

“Zapiski Mikhaila Chaykovskogo (Sadyk Pashi)”, Kiyevskaya starina, 1891, 1892

A. Zlatanov, "Kazak alayat na Sadyk pasha”, Izvestiya na intituta za istoricheski izsleduvaniya, T.32, Sofiya, 2015

Alisiya Kulets'ka, “Pomizh Pol'shcheyu, Turechchinoyu i Rosiyeyu: Mikhal Chaykovs'kiy (Mekhmet Sadik pasha) i problemi “kozachchini" v XIX st.", Prichornomors'kiy region u konteksti svitovoï politiki: istoriya ta s'ogodennya, Odesa, 2008

B. Penev, “Istoriya na novata bolgarska literatura”, T. IV Sofiya, 1936

Candan Badem, “The Ottoman Crimean War (1853-1856)", Leidem-Boston, 2010

D.Sen', A. Prigarin “Panslavizm Mikhala Chaykovskogo i istoriya kazachestva v Osmanskoy imperii”, Polyaki v istorii Rossii: istoriya i sovremennost', Krasnodar, 2007, S.147-160

Fr. Rawita-Gawronski, “Michal Czaykowski (Sadyk-pasza). Jego zycie, dzialalnosc wojskowa i literacka. Zarys biograficzny", Petersburg, 1901

I. Lysyak-Rudnits'kiy, “Kozats'kiy proyekt Mikhala Chaykovs'kogo pid chas Krims'koyi viyny: analiz idey”, Lisyak-Rudnits'kiy I. Istorichni ese, K., 1994, T. 1

I. Shishmanov, "Studii iz oblasta na bolgarskoto vozrazhdane", Sbornik Bolgarskoy Akademii na Naukite, 4, 1916

I.K. Stoychev, "Kazak-alaya na Chaykovski”, Sofiya, 1944

J. Chudzikowska, “Dziwne życie Sadyka Paszy o Michal e Czajkowskim”, 1971

Jerzy S. Łątka, “Słownik Polaków w Imperium Osmańskim i Republice Turcji”, Kraków, 2005

K. Sukhodolska, "Bolgarite v neizdanite memuari na Chayka Chaykovski (Sadyk-pasha)", Sbornik za narodni umotvoreniya, nauka i knizhnina, Kniga X. Sofiya, 1894 
M. Czajkowski, “Moje wspomnienia o wojnie 1854 roku”, Warszawa, 1962

M.Arnaudov, "Neofit Khilendarski Bozveli (1785-1848)", Sofiya, 1930

M.Czajkowski “Pamietniki Sadyka Paszy Michal a Czajkowskiego”, Lwow, 1898

M.Rybak, “Mikhaylo Chaykovs'kiy - Megmet Sadik Pasha», Al'manakh ukraíns'kogo natsional'nogo soyuzu, New York, 1971

M.S. Chaykowskiy, "Zapiski” Russkaya starina,1895-1898, 1900, 1904

Unver Metin Ünver, “Wanda ya da Mehmed Sadik (Cayka) pasa'nin turkiye anekdotlari”, Tarih Dergisi, 65, 2017, s. 99-118.

Michał Czaykowski. “Kozaczyzna w Turcyi”, Paryż, 1857

Musa Gümüs, “Mehmed Sadik Pasa (Michal Czajkowski) ve Osmanli devlet'nde kazak suvari alayi”, Turkish studies, V. 5/3, 2010

0 . Prigarin, «Kozatstvo v Turechchini» M. Chaykivs'kogo yak dzherelo vivchennya kozats'kikh formuvan' v Ottomans'kiy Porti seredyny XIX st.", Naukovi pratsi istorichnogo fakul'tetu Zaporiz'kogo derzhavnogo universitetu, 2001, Vyp. XIII, S.26.

P. Wierzbicki, “Dziennik generala Feliksa Breanskiego, dowodcy brygady w Dywizji Kozakow Sultanskich”, Akta THL v Paryzu, 2000, T. 5

T. Slabchenko, "Koly povernuv na Ukrayinu Sadyk-Pasha?" Zapiski Istoriko-Filologichnogo Viddilu Vseukrayins'koyi Akademiyi Nauk, Kn. XXV, K., 1929

V. Poltorak, “Dokumenty pro M. Chaykovs'kogo v Derzhavnomu arkhivi Odes'koyi oblasti», Chornomors'ka mynuvshina, Vyp. 5, Odesa, 2010.

V. Smokhovska-Petrova, "Neofit Bozveli i bolgarskiyat tserkoven vopros". Sofiya, 1964

V.Smokhovska-Petrova, "Mikhal Chaykovski - Sadyk pasha i Bolgarsko vozrazhdene”, Sofiya, 1973

Ye. Khadzhinikolova, "Mikhail Chayka-Chaykovski (Mekhmed Sadyk pasha) i bolgarite v Tulchanski sandzhak (50-70-te godini na XIX v.)", Chornomors'ka mynuvshyna, 2010, №3

Ye. Rudnits'kiy, “Do istoriyi pol's'kogo kozakofil'stva”, Za sto lit, Kn. 1, 1925, S. 62-66

Yu. Borisonok, “Ataman Sadyk-pasha”, Rodina, 1998, №5-6 